\title{
Northern lobby attacks UK synchrotron siting
}

London

So, the largest single investment in science infrastructure in Britain in two decades is to be made at the Rutherford Appleton Laboratory (RAL) near Oxford. But the decision

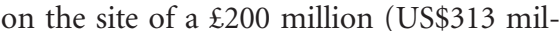
lion) synchrotron (see Nature 404, 221; 2000) has sparked bitter protests from supporters of the rival Daresbury Laboratory near Manchester.

The synchrotron is a partnership between the British and French governments and the Wellcome Trust. Its powerful X-ray beamlines will be used to determine the structure ofbiological molecules and advanced materials. "The most important thing is that a decision to go ahead has been made," says John Finney, of University College London, a physicist who also studies biological molecules. Already, a year has been spent wrangling over the synchrotron's location.

Labour Members of Parliament from neighbouring northwestern constituencies lobbied hard for Daresbury. They had the ear of the trade and industry secretary, Stephen Byers. But the Wellcome Trust, and the Office of Science and Technology, which Byers oversees, argued for RAL. The decision was finally taken at cabinet level with Prime Minister Tony Blair directly involved.

RAL's backers argue that there are synergies to be gained from housing the synchrotron next to other facilities at RAL, such as the ISIS neutron source. Building up the RAL campus might also make it more attractive as a potential site for the planned European Spallation Source, another neutron facility.

But Daresbury's supporters complain of a lack of transparency over the decision. "This is not a spat, this is war," says Ian Gibson, MP for Norwich North and formerly Dean of Biological Sciences at the University of East Anglia. Gibson is also a member of the House of Commons Science and Technology Committee, which last year argued that there was no clear scientific case for favouring one site over the other.

Many MPs are angry about the possibility that the decision will widen the economic gap between the prosperous south and the depressed north. "The distribution of science excellence should be closely allied to regional development policies," argues Gibson.

The large and vocal lobby behind Daresbury, which includes 70 Labour MPs, five local universities, and two Nobel Prize winners, is particularly annoyed with the Wellcome Trust. Including running costs over 25 years, the synchrotron will cost $\mathfrak{E} 550 \mathrm{~m}$. The trust will contribute $£ 110 \mathrm{~m}$, and the government says that the trust's preference for RAL was the deciding factor in the siting decision.

Helen Southworth, MP for Warrington South, complains that trust officials refused

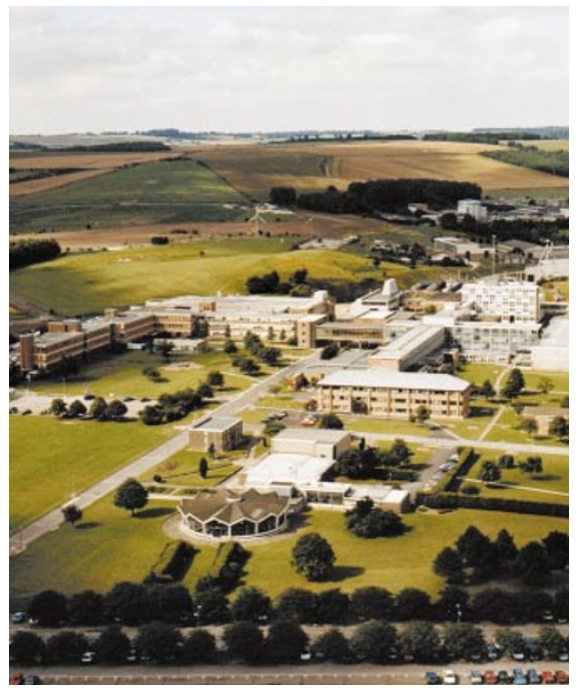

Southern comfort: the Rutherford Appleton Laboratory, victor in synchrotron decision.

to meet a delegation of MPs. "I find that incomprehensible," she says. A spokeswoman denied that Wellcome Trust director Mike Dexter had refused to meet the MPs, but said he had been unable to find time to do so.

Staff at Daresbury, which is home to
Britain's existing national synchrotron, are similarly enraged. "The people who have got this work off the ground are at Daresbury; then it is stolen at the last minute and that really hurts," says a union representative.

Some users fear that vital expertise will be lost as technical staff take other jobs, rather than transfer to RAL. They are also worried about a possible gap in the availability of experimental facilities. "I suspect that many beamlines, including the one I am using now, will stop functioning properly because oflack of expertise well before the new machine becomes available," says Michael Ferenczi, a biophysicist at the National Institute for Medical Research in London.

Meanwhile, Southworth and other proDaresbury MPs are vowing not to give up, and met the Prime Minister to press their case earlier this week. Many future users of the synchrotron are sympathetic with their fight, but there are fears that a prolonged row could delay construction work. This is due to start next year, and planning permission still has to be obtained. "Now the community has to try to rebuild across the serious rifts that have been induced by this whole affair," says Finney.

\section{French minister feels the heat over Soleil}

Paris

Arguments used by French science minister Claude Allègre in favour of cooperating with Britain on a new synchrotron rather than building a national source in France have come under fire in a parliamentary report. The report from the Office of Evaluation of Scientific and Technological Choices, urges that France immediately explore building an $X$-ray source on French soil.

Allègre had justified his decision to join the British government and the Wellcome Trust in building the synchrotron ring, Diamond, primarily on the grounds that a national synchrotron source built in France would be an economic burden, and that he was keen to see all 'big science' facilities built through European-level cooperation.

But the parliamentary document, released last Thursday, argues on the basis of evidence from more than $\mathbf{4 0}$ witnesses from throughout Europe that a national source would be the most economical way of meeting the needs of French researchers. It says that the total costs to France per beamline on Diamond would be at least 50 per cent higher than on a national facility.

The report also criticizes Allègre's suggestion that France later rent beamlines in Switzerland and Germany, arguing that these facilities are already oversubscribed. "With a key technology such as synchrotron radiation, it would be harmful for France to adopt a short-term vision, probably reducing expenses very little, and certainly compromising the long-term potential of French research," states the document, which was written by deputy Christian Cuvilliez (Partie Communiste, Seine-Maritime) and Senator René Trégouët (RPR, Rhône).

When Allègre announced the French partnership in Diamond last summer, he also signalled the end of Soleil, a proposal ten years in the making to replace France's only national synchrotron facilities at the Laboratoire pour l'Utilisation du Rayonnement Electromagnétique near Paris.

"The exclusive resort to international cooperation to satisfy national needs would appear somewhat paradoxical when France finds itself equipped with competitive resources... [and] the notion of scientific competition is more than ever present in the strategies of developed countries," states the report.

Cuvilliez and Trégouët support French participation in Diamond as an extra investment in synchrotron radiation to benefit disciplines such as biology. But during a press conference last Thursday, Cuvilliez called for the project to build Soleil to be relaunched.

The report is unlikely to have an immediate impact on the government's thinking. But it could be politically damaging to Allègre, who is already facing strong criticism from the ranks of his own Socialist Party for his handling of educational reforms. Heather McCabe 